\title{
HAROLD HERBERT PITTMAN, 1889-1972 A MEMORIAL TRIBUTE
}

\author{
by C. Stuart Houston, 863 University Drive, Saskatoon
}

Harold Herbert Pittman died on August 29, 1972 in the Regina General Hospital after a lengthy illness. He will be known to some readers from three early articles in the Blue Jay, and the brief summary of his field records in Nero's Birds of Moose Mountain, Saskatchewan - yet few people in Saskatchewan appreciated the extent of his writings or the preeminence of his nature photography. He was undoubtedly one of the most knowledgeable, all-round naturalists to live in Saskatchewan. Though birds were only one of his interests, his incomplete field notebooks recorded breeding records of 74 Saskatchewan species within a few miles of Wauchope.

H. H. Pittman was born in London, England in June, 1889, the son of John and Clara (Wakelin) Pittman. He was

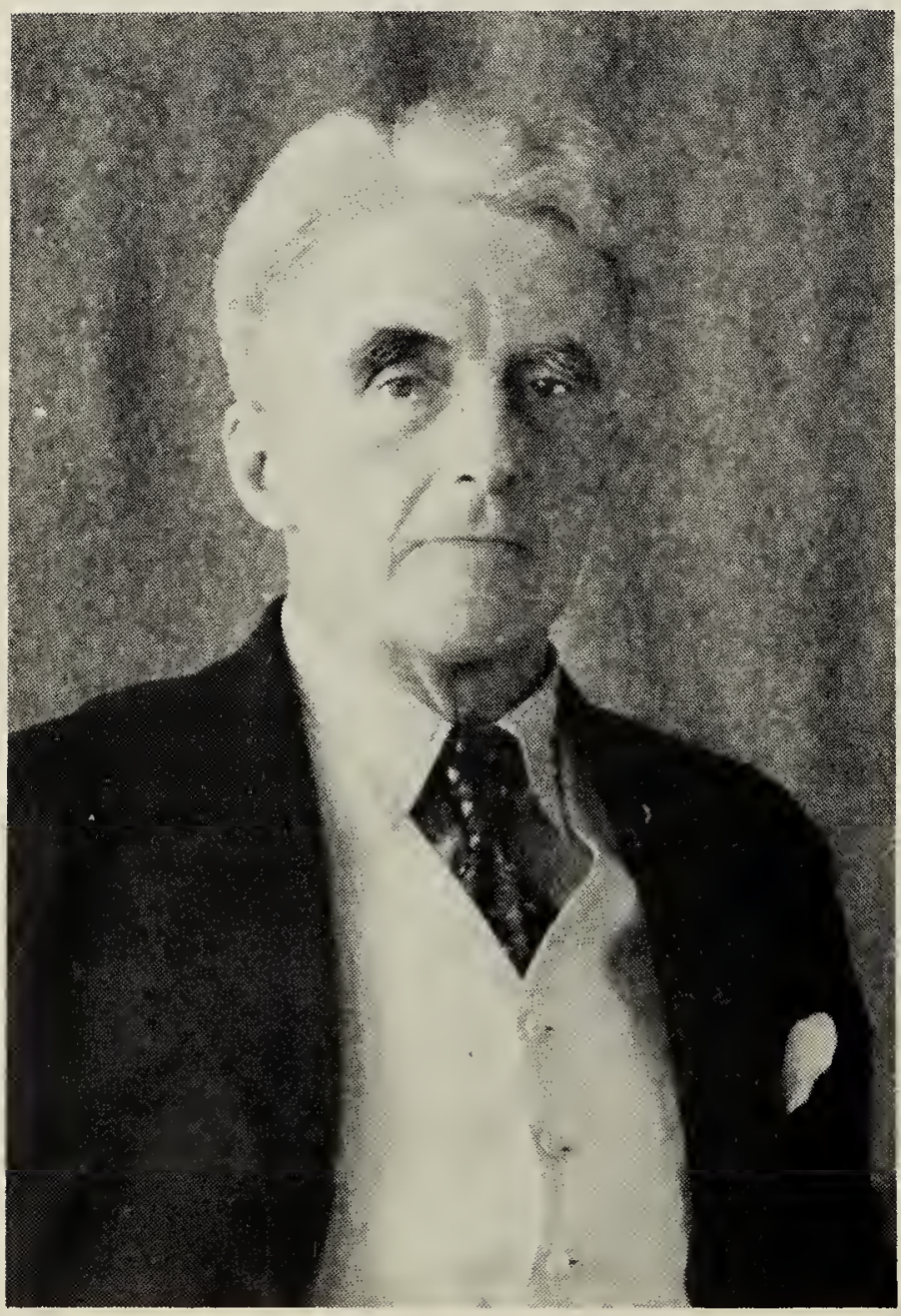

H. H. Pittman educated at King's College School on the Strand. He made his first visit to relatives near Wauchope, Saskatchewan in 1905 at the age of 16 , and at once decided that this was the best place in the world to pursue his hobby of studying and photographing nature He returned to Canada on visits in 1907 and 1912 and emigrated permanently in 1913. Throughout his lifetime, no matter how difficult the times nature study and photography were his quiet, solitary and almost all-consuming hobbies.

He homesteaded briefly near Red Deer, Alberta and worked on the first railway to Lesser Slave Lake in the winter of 1913-14. In 1914 he married Elizabeth O'Higgins and after about a year at Wauchope, they moved to Hartney, Manitaba. They returnec permanently to the village of Wau chope in September, 1923, where his wife predeceased him in 1947.

In his own words, Pittmar "attempted to popularize the study of natural history." This was don through articles and photographs pub lished in many journals in Britain an the United States, though unfortun ately many of these had little circula tion in Saskatchewan. For some years he contributed to A. G. Lawrence', column, "Chickadee Notes", in th Winnipeg Free Press. Largely becaus of geography and partly due to hi temperament, he studied nature b: himself. In late June, 1921, P. A Taverner and Hoyes Lloyd campes overnight in his yard at Hartney Manitoba. I corresponded with $\mathrm{Mr}$ Pittman on a few occasions beginning in 1942, and Mary and I visited hin in St. Mary's home, Weyburn, if April, 1971, when his memory fo recent events was already failing.

Collections of his photographs wer exhibited in Winnipeg (date?), St Louis (March, 1942) and New Yor] 


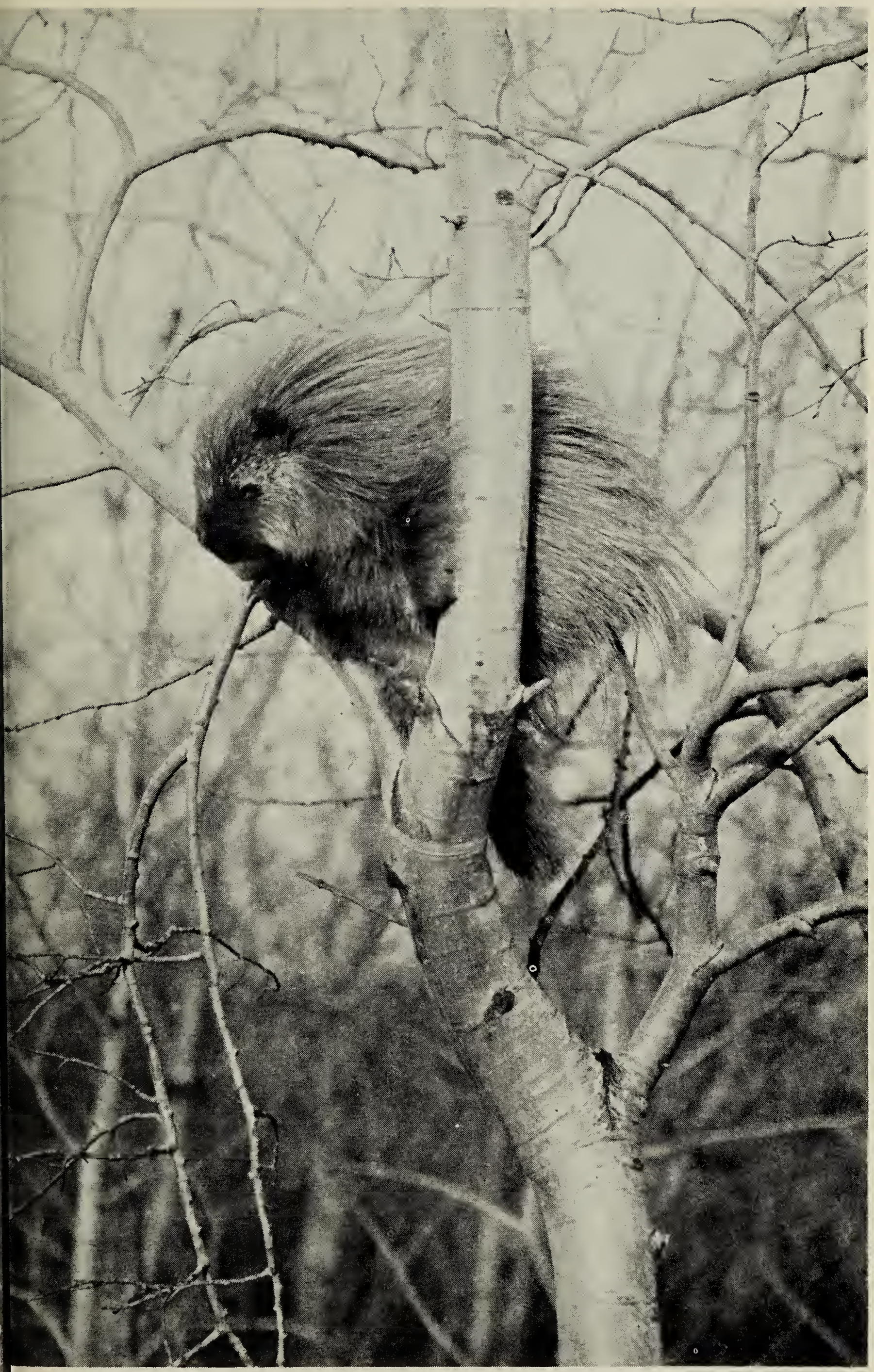

estern Yellow-haired Porcupine

Photo by H. H. Pittman, Wauchope 


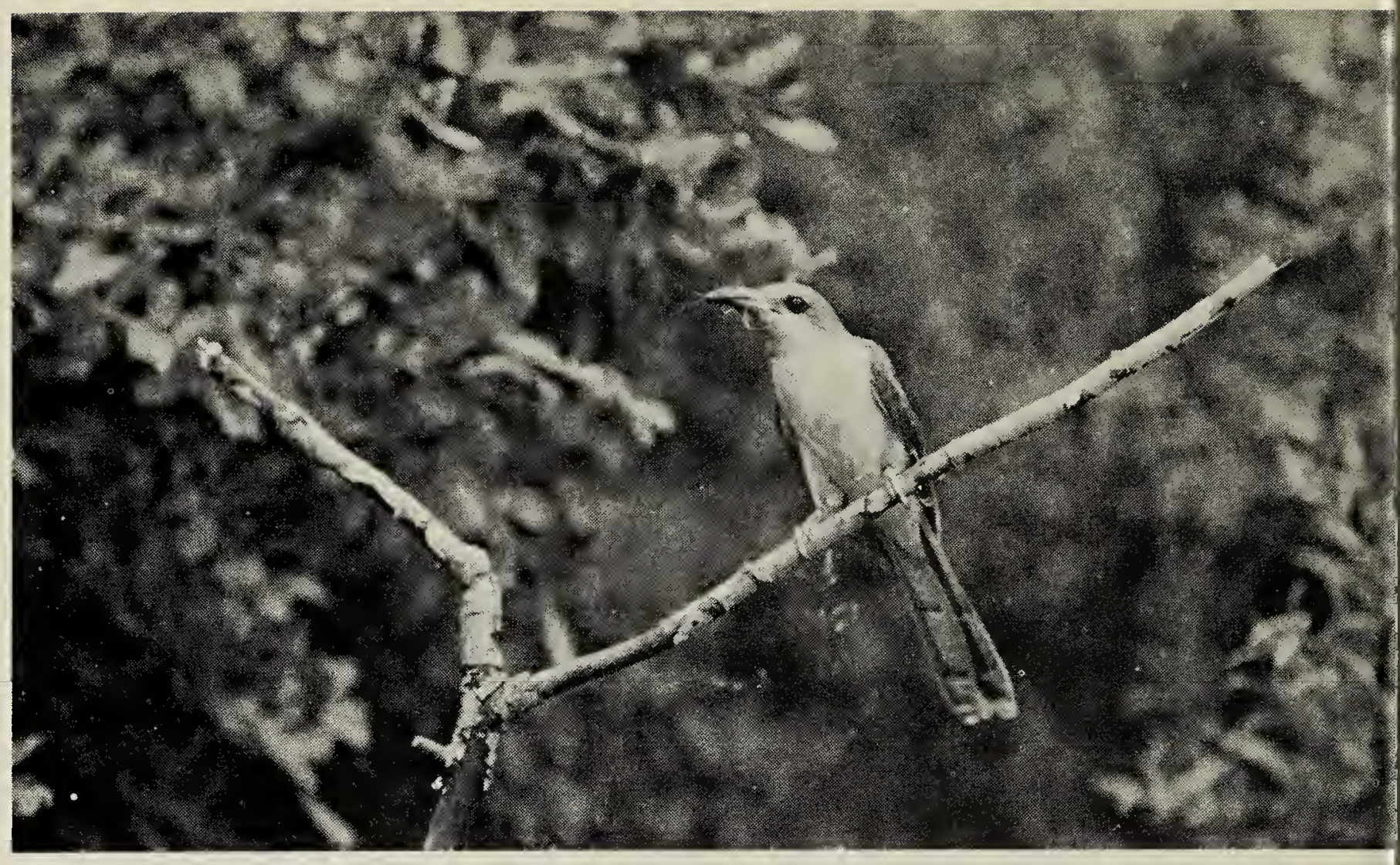

Female Black-billed Cuckoo with grasshopper

Photo by H. H. Pittm

City (1947). In addition to many photographs used to illustrate his articles, at least 31 individual photographs were used by Bird Lore (now Audubon Magazine) between 1916 and 1932, with an occasional use of others as late as 1965. Two of his photographs of Sharp-tailed Grouse in winter and one of downy Killdeers, were used in Bent's Life Histories. These photographs were of a remarkable quality, considering that all were obtained with an old-fashioned single plate camera purchased about 1905. $\mathrm{Up}$ to 20 minutes of preparation and careful focussing were required before each exposure; usually his wife assisted him in this delicate operation.

I wish to thank his daughters, Mrs. Gertrude Van den Boer and Miss Pat Pittman, both of Manor, Sask., for the generous loan of their father's field notebooks. The exhibit collection of his photographs has been donated to the Saskatchewan Archives, Saskatoon and the remaining portion of his egg collection to the Biology Museum, Saskatoon campus, University of Saskatchewan.

The following incomplete list of his published articles, almost all illus- trated with his own photographs, h been compiled by Mary Houston. will serve to demonstrate the wi range of his interests.

Bird-Lore

Jan.-Feb. 1916. 18:1-6. Some Can dian Grouse ( 8 ill.)

Nov.-Dec. 1917. 19:332-33. The Amer can Crossbill (1 ill.)

Jan.-Feb. 1918. 20:55. Snowy O (1 ill.)

Mar.-Apr. 1925. 27:92-96. The Fo of the Western Horned Owl (3 ill July-Aug. 1926. 28:262-64. Som Notes on Sitting Birds ( 1 ill.)

Jan.-Feb. 1928. $30: 5-7$. Mallards the Prairie ( 1 ill.)

May-June 1928. 30:181-82. Canada New Bird (1 ill.)

Sept.-Oct. 1929. 31:327-29. A Ra with a Rail ( ( 2 ill.)

Nov.-Dec. 1929. 31:393-95. Herdir the Birds ( 1 ill.)

Sept.-Oct. 1931. 33:318-20. Field Not on Marbled Godwits I (3 ill.)

Audubon Magazine

July-Aug. 1960. 62:168-69. A Gor Samaritan (2 ill.) 
Vature Magazine

ct. 1937. 30:205-06. Protective Resemblance in Nature ( 3 ill.)

uly 1942. 35:299-301. The Blackbilled Cuckoo (4 ill.)

eb. 1943. 36:91-92, 105. Ogres of the Prairie (2 ill.)

ct. 1943. 36:405-06. Clay - colored Sparrow (3 ill.)

uly 1944. 37:299-301. The Long-tailed -Weasel ( 4 ill.)

pr. 1947. 40:190-91. Goldfinches in Saskatchewan (2 ill.)

ept. 1948. 41:373-74. Architects with Leaves ( 3 ill.)

tar. 1949. 42:125-26. The Brown Shrew (2 ill.)

aly 1949. 42:266, 292. Grasshopper Mice (1 ill.)

aly 1951. 44:299-300. The Female Phalarope Is Boss (2 ill.)

ept. 1952. 45:378-79, 386. Garter Snakes in Saskatchewan (2 ill.) eb. 1953. 46:75-76, 108. The Kestrel (2 ill.)

pr. 1954, 47:209-10, 218. Painted Turtles in Saskatchewan (3 ill.)
Mar. 1955. 48:135-36. Sprague's Pipit and Others (4 ill.)

July 1955. 48:317. An Albino Holboell's Grebe (1 ill.)

May 1956. 49:237-39. Sandhill Cranes in Retrospect ( 6 ill.)

Jan. 1958. 51:24. Prairie Gulls (1 ill.)

May 1959. 52:257. Butterflies in the Rain (1 ill.)

Condor

1927. 29:140-43. The Black Terns of Saskatchewan (4 ill.)

Canadian Field-Nat.

1926. 40:60-62. The Prairie Pocket Gopher (2 ill.)

Can. Geographical Journal

1932. $4: 131-34$. Prairie Hares in Winter ( 4 ill.)

1933. 7:127-132. The Prairie Orchestra (9 ill.)

1955. 51:198-205. Gophers of the Prairie (8 ill.)

Journal of Mammalogy

1924. 5:231-33. Notes on Feeding Habits of the Little Brown Bat (2 ill.)

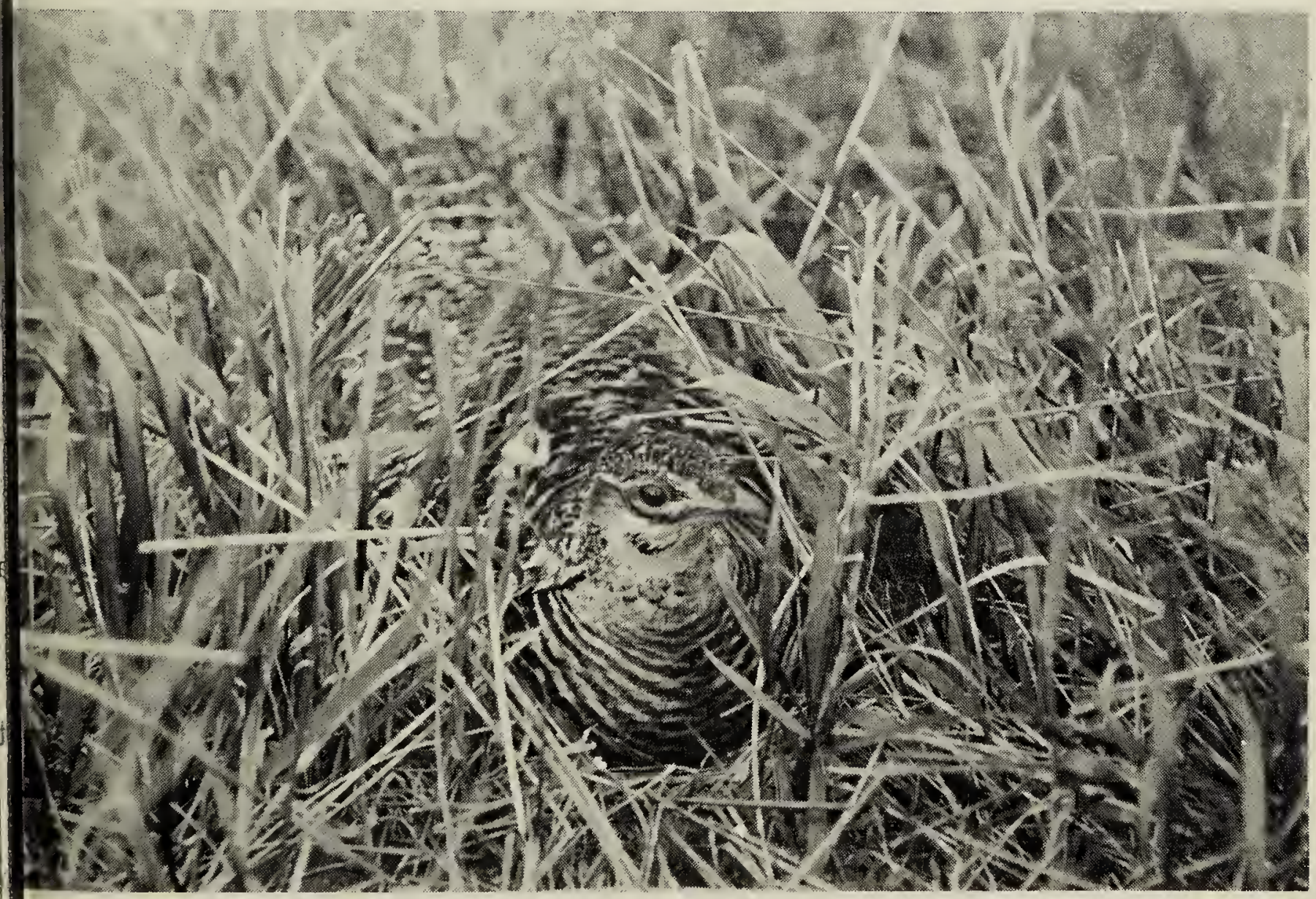

eater Prairie Chicken on nest

Photo by H. H. Pittman 


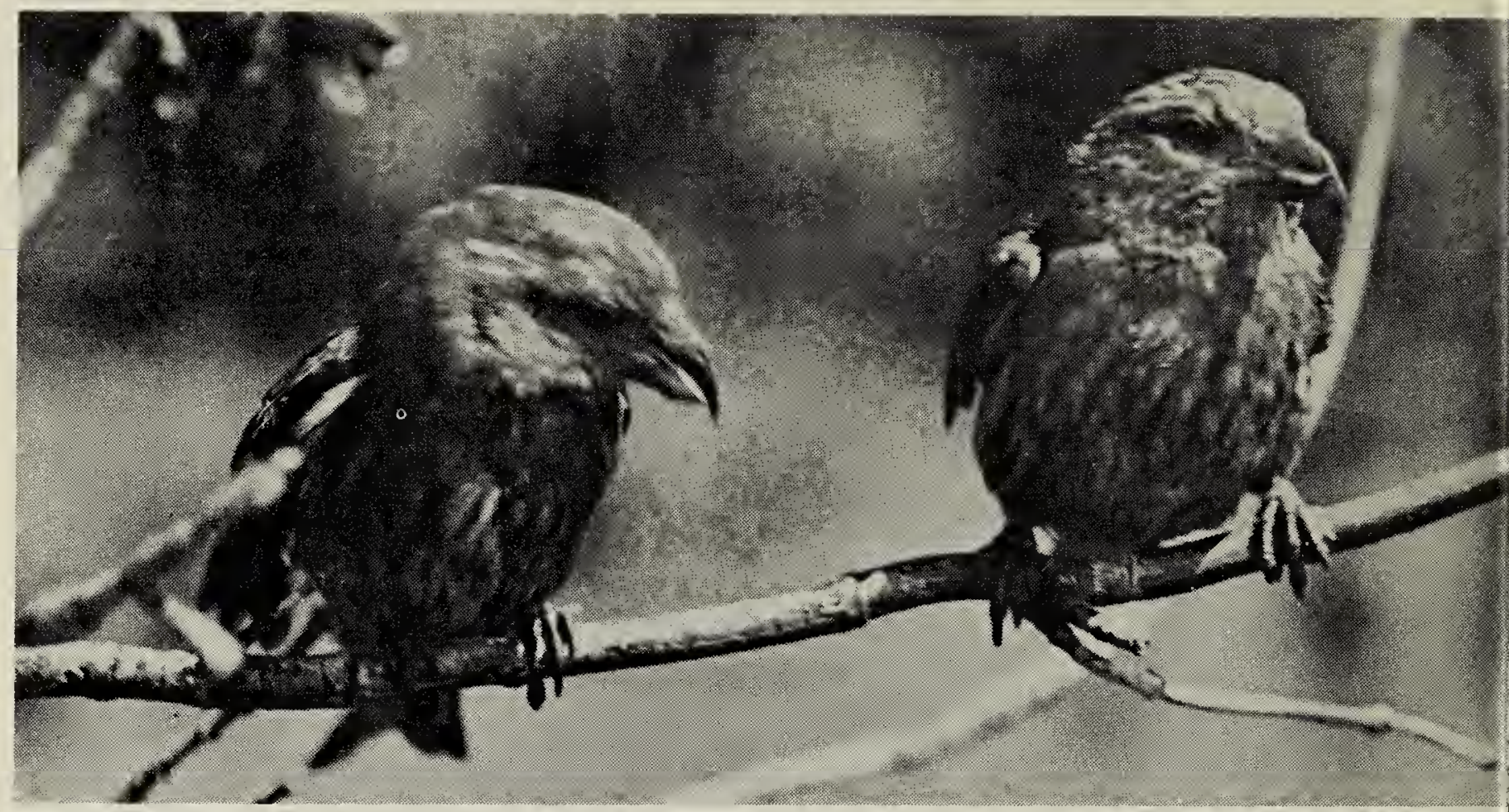

Young Red Crossbills

Photo by H. H. Pittma

Blue Jay

1944. 2:27-28. Swainson's Hawk (no ill.)

1957. 15:58-59. Saving the Cranes (1 ill.)

1959. 17:30. Short-tailed Shrew at Wauchope ( (no ill.)

American Field

Sept. 16, 1911. Wading for Ducks in Manitoba

Rod and Gun

Aug. 1927. Among the Branches

Science Gossip

Jan. and Feb. 1910. Some Canadian Animals.

\section{Outdoor Canada}

May 1945. Swainson's Hawk

July 1945. Our Largest Moths

Oct. 1945. Skunks

Oct. 1945.Gophers

Oct. 1945. Bats in Saskatchewan

Nov. 1945. Home Wrecking Wren

Jan. 1946. Round Stones

Jan. 1946. Nuthatches

Mar. 1946. Animal without a friend; My friend the Toad

May 1946. Stone Arrowheads

July 1946. Nighthawks on the Prairies

Aug. 1946. Dance of the Prairie Chickens

May 1947. Plovers

Aug. 1947. Antennae of Butterflies and Moths
Dec. 1947. Some Notes on Seed Dis persal

Jan. 1949. Prairie Turtles

Apr. 1949. Saskatchewan Killdeer

Sept. 1949. Prairie Fossils

Wild Life

1914. On Some Canadian Rodents

Illustrated London News

Feb. 18, 1911. Sportsmen's Paradise Canada for the Hunter and Fisher man.

In addition, Pittman sold illustrate articles to the following popular news papers and magazines:

Country-side Monthly: Four article on mammals, 1910-1914.

Country Life: 20 articles including on birds and 11 on mammals, 191? 1925.

The Nor'-West Farmer: 2 articles o mammals, 1915.

The Country Guide: 6 articles, includ ing 2 on birds, 1930-1955.

The Western Home Monthly: 1 articles, wide variety of subject 1917-1922.

In addition, there were one to thre articles in Grain Growers Guide Family Herald, Free Press Prairi Farmer, Regina Leader-Post, Winn peg Free Press, Western Produce Toronto Star Weekly and the Mor treal Standard. 